Studia Theologica Varsaviensia

UKSW

$2 / 2020$

Ks. Michal Pierzchąa

\title{
OBRAZ SAMARYTAN W TRZECIEJ EWANGELII KANONICZNEJ
}

Samarytanie byli w mniemaniu członków Narodu Wybranego uważani za nieczystych m.in. z powodu odstępstwa od kultu w Świątyni Jerozolimskiej. Wzajemne odniesienie Żydów i Samarytan było bardzo negatywne, a wręcz wrogie czego przykładem są chociażby reakcja Jakuba i Jana na odmowę przyjęcia Chrystusa w miasteczku samarytańskim (zob. Łk 9, 51-56) lub sposób rozmowy kobiety z Chrystusem przy studni Jakuba (por. J 4, 9). Jednakże gdy współcześnie mowa o Samarytanach z pewnością wiele skojarzeń jest bardzo pozytywnych i biegnie chociażby ku przypowieści o Miłosiernym Samarytaninie, która jest jedną z najpiękniejszych paraboli ukazujących stosunek Boga do swych zranionych grzechem synów i córek. Wobec tego rodzi się pytanie o przedstawienie obrazu samarytańskiego w trzeciej Ewangelii kanonicznej oraz o wpływ Łukaszowych perykop na współczesne, pozytywne skojarzenia z mieszkańcami wzgórz Samarii. Niniejszy artykuł będzie także próbą refleksji nad aktualnością przesłania przypowieści o Miłosiernym Samarytaninie w bieżącym kontekście pandemii nie tylko koronawirusa, lecz także egoizmu i indywidualizmu.

Współcześnie można dostrzec deficyt empatii jako postawy egzystencjalnej wyrażającej się w dostrzeganiu i świadczeniu pomocy 


\section{PICTURE OF THE SAMARITANS IN THE THIRD GOSPEL}

The Samaritans were considered unclean by the members of the Chosen People because of their deviation from the cult of the Temple in Jerusalem, among other reasons. Mutual relations between Jews and Samaritans were very negative, even hostile, as exemplified by the reaction of James and John to the refusal to accept Christ in the Samaritan town (see Luke 9:51-56) or the way the woman talked to Jesus at Jacob's well (cf. John 4:9). However, in contemporary terms, the Samaritans are certainly associated in a very positive way with the parable of the Good Samaritan, which is one of the most beautiful parables depicting God's attitude towards his sons and daughters wounded by sin. This raises the question of the representation of the Samaritan image in the third Gospel and the influence of Luke's pericopes on contemporary, positive associations with the inhabitants of the hills of Samaria. This paper also attempts to reflect on the validity of the message of the parable of the Merciful Samaritan in the current context of a pandemic not only of coronavirus, but also of selfishness and individualism.

Nowadays there is a deficit of empathy as an existential attitude expressed in perceiving and helping one's neighbour'. In today's world we can see ever stronger divisions between people, whose

${ }^{1}$ Cf. Z. Uchnast, Empatia jako postawa egzystencjalna [Empathy as an Existential Attitude], „Roczniki Filozoficzne” vol. 44, issue 4, 1996: 37-52. 
bliźniemuํ. W dzisiejszym świecie uwidaczniają się coraz silniejsze podziały międzyludzkie, czego jedną z przyczyn są m.in. lansowane w mass mediach hedonizm i egocentryzm jako klucze do pozornego szczęścia. Odwołując się do najnowszej encykliki papieża Franciszka o braterstwie „Fratelli tutti”, można odnaleźć trafne i jakże aktualne stwierdzenie, iż: „Indywidualizm nie czyni nas bardziej wolnymi, bardziej równymi, bardziej braćmi. Nie może nas też uchronić od wielu nieszczęść, które stają się coraz bardziej globalne. Radykalny indywidualizm jest wirusem najtrudniejszym do pokonania" ${ }^{2}$.

Zaprezentowany przez św. Łukasza stopniowo zmieniający się obraz Samarytan pokazuje, iż braterska miłość nie bierze się ex nihilo, lecz wynika ze zmiany myślenia - metanoi - będącej zawsze darem łaski Bożej. Przypowieść o Dobrym Samarytaninie zaprasza do przemiany myślenia odbiorcę zarówno ówczesnego, jak i dzisiejszego usprawiedliwiającego się pytaniem „A kto jest moim bliźnim?” (zob. Łk 10, 29).

Niniejszy artykuł będzie próbą odpowiedzi na pytania, jaki obraz Samarytan zaprezentował autor trzeciej Ewangelii kanonicznej oraz jakie wskazania z owej prezentacji płyną dla współczesnych odbiorców. W poszukiwaniu odpowiedzi na powyższe pytania pomocna będzie próba przybliżenie tła historycznego oraz niektórych kwestii etymologicznych związanych z Samarytanami.

\section{GENEZA I HISTORIA SAMARYTAN}

W obiegowym rozumieniu proweniencji Samarytan upatruje się w zmieszaniu ludności izraelskiej z Asyryjczykami w czasie najazdu na Królestwo Północne w 722 r. prz.Chr. ${ }^{3}$, co spowodowało, iż zasiedlili oni tereny Samarii (por. Ezd 4,9-10), gdy najeźdźcy wypędzili

\footnotetext{
1 Por. Z. Uchnast, Empatia jako postawa egzystencjalna, „Roczniki Filozoficzne” t. 44, z. 4, 1996: 37-52.

2 Franciszek, Encyklika Fratelli tutii, Watykan 2020, nr 105.

3 Por. F. Rienecker, G. Maier, Leksykon biblijny, w: Prymasowska Seria Biblijna, Warszawa 2001, s. 720.
} 
causes include hedonism and egocentrism promoted by the mass media as the keys to apparent happiness. Referring to Pope Francis' latest encyclical on fraternity and social friendship, Fratelli tutti, one can find an apt and very timely statement that:

"Individualism does not make us more free, more equal, more fraternal. The mere sum of individual interests is not capable of generating a better world for the whole human family. Nor can it save us from the many ills that are now increasingly globalized. Radical individualism is a virus that is extremely difficult to eliminate, for it is clever."2

The gradually changing image of the Samaritans presented by St. Luke shows that fraternal love is not born ex nihilo, but results from a change of mind - metanoia - which is always a gift of God's grace. The parable of the Good Samaritan invites the contemporary person to change his or her way of thinking by asking: "who is my neighbour? (see Lk 10:29).

This paper attempts to answer the questions: What image of the Samaritans did the author of the third Gospel present, and what indications does this presentation give to contemporary audiences? In the search for answers to these questions it will be helpful to try to provide some historical background and some etymological issues related to the Samaritans.

\section{ORIGIN AND HISTORY OF THE SAMARITANS}

Samaritans are claimed to have been Israelite descendants of the Northern Israelite tribes of Ephraim and Manasseh, who survived the destruction of the Kingdom of Israel (Samaria) by the Assyrians in $722 \mathrm{BCE}^{3}$, which led them to settle in the area of Samaria (cf. Ezra 4:9-10), when the invaders had expelled some

2 Francis, Encyclical Letter Fratelli tutii, Vatican 2020, no. 105.

3 Cf. F. Rienecker, G. Maier, Dictionary of the Bible [original: Lexikon zur Bibel], in: Prymasowska Seria Biblijna [Primate Bible Serie], Warsaw 2001, p. 720. 
z Izraela około 40000 Żydów4 . Kolejno w historii relacji żydowsko-samarytańskich pojawiało się wiele napięć. Jedną z ważnych przyczyn napiętnowania Samarytan przez Żydów był synkretyzm kultowy wyrażający się w oddawaniu czci Jedynemu Bogu oraz bogom babilońskim, akadyjskim czy sumeryjskim w czasie niewoli asyryjskiej5. Następnie kością niezgody stała się odbudowa Świątyni po powrocie Żydów z niewoli Babilońskiej, do której nie dopuszczono Samarytan pewnie z uwagi na ich nieczystość powstałą m.in. z wyżej opisanych przyczyn $^{6}$. Dlatego Samarytanie wznieśli alternatywną świątynie na górze Garizim, gdzie, jak twierdzą, jest jedyne, prawdziwie wybrane przez Boga i uprzywilejowane miejsce $\mathrm{czci}^{7}$. Tradycja samarytańska na Garizim umiejscawia liczne biblijne wydarzenia związane m.in. z życiem Abrahama czy Noego ${ }^{8}$. Mimo że opozycyjna świątynia do jerozolimskiej została zburzona przez Jana Hirkana w 128r. pz.Chr., to jednak wciąż góra Garizim jest uznawana za świętą przez Samarytan ${ }^{9}$. Należy wspomnieć także dialog Mistrza z Nazaretu z kobietą przy studni Jakuba w Samarii (por. J 4, 1-42), który porusza kwestię autentycznego miejsca oddawania czci oraz rozumienia istoty Boga czczonego przez oba narody mimo podziałów ${ }^{10}$.

W dyspucie na temat Samarytan niemałym problemem zdaje się być kwestia terminologii. Samo określenie Samarytanie pojawia się w Starym Testamencie tylko raz w 2 Krl 17,29 i wywodzi się prawdopodobnie od hebrajskiego czasownika רמש (šāmar), który oznacza

4 Por. S. Wypych, Samarytanie w ujęciu historycznym, geograficznym i religijnym, w: RBL 3 (2005), Lublin 2005, s. 171n.

5 Tamże.

6 Por. F. Rienecker, G. Maier, dz. cyt., s. 720.

${ }^{7}$ Por. M. Bednarski, Obraz Samarytan $w$ okresie rzymskim i ich relacje ze wspólnotą żydowska w świetle dzieł Józefa Flawiusza, w: Veritati et Caritati 4 (2015), Częstochowa 2015, s. 63n.

8 Tamże.

9 Por. S. Wypych, art. cyt., s. 173.

10 Zob. S. Mędala, Ewangelia wg św. Jana, w: NKB NT IV/1, Częstochowa 2010, s. 464n. 
40,000 Jews from Israel ${ }^{4}$. Numerous tensions arose successively in the history of Jewish-Samaritan relations. One of the important reasons for the stigmatization of the Samaritans by the Jews was their cultic syncretism expressed in the worship of the One God and Babylonian, Akkadian and Sumerian gods during the Assyrian captivity $^{5}$. Then the bone of contention became the rebuilding of the Temple after the return of the Jews from Babylonian captivity, to which the Samaritans were not allowed, presumably because of their impurity, among other reasons described above ${ }^{6}$. That is why the Samaritans erected an alternative temple on Mount Gerizim, where, they claim, is the only truly God-chosen and privileged place of worship ${ }^{7}$. Samaritan tradition sets numerous biblical events on Gerizim, including the lives of Abraham and Noah ${ }^{8}$. Although the temple which is believed to have been in opposition to Jerusalem's was demolished by John Hyrcanus in 128 B.C., Mount Gerizim is still considered holy by the Samaritans ${ }^{9}$. Some reference should also be made to the dialogue between the Master of Nazareth and the woman at Jacob's well in Samaria (cf. Jn 4:1-42), which raises the question of the authentic place of worship and the understanding of the essence of God worshipped by both tribes despite the divisions ${ }^{10}$.

In the dispute about the Samaritans, the question of terminology seems to be a significant problem. The very term Samaritans

${ }^{4}$ Cf. S. Wypych, Samarytanie w ujęciu historycznym, geograficznym i religijnym [Samaritans in Historical, Geographical and Religious Perspective], in: RBL 3 (2005), Lublin 2005, p. 171n.

5 Ibid

${ }^{6}$ Cf. F. Rienecker, G. Maier, ed. cit., p. 720.

7 Cf. M. Bednarski, Obraz Samarytan $w$ okresie rzymskim i ich relacje ze wspólnotą żydowską w świetle dziet Józefa Flawiusza [The Image of the Samaritans in the Roman Period and Their Relations with the Jewish Community in the Light of the Works of Josephus Flavius], in: Veritati et Caritati 4 (2015), Częstochowa 2015, p. 63 n.

8 Ibid.

9 Cf. S. Wypych, art. cit., p. 173.

10 See S. Mędala, Ewangelia wg św. Jana [The Gospel According to John], in: NKB NT IV/1, Częstochowa 2010, p. 464n. 
czuwać lub strzec ${ }^{11}$. Nazwa Samarytanie nie niesienie z sobą jednoznacznego desygnatu. Może oznaczać zarówno mieszkańców Samarii, a więc pogan albo wyznawców religii mojżeszowej lub ludność sprawującą własny kult na górze Garizim pozostającą w opozycji do kultu Boga Izraela w Jerozolimie. Flawiusz, opisując mieszkańców Samarii, posługuje się terminami takimi jak $\Sigma \alpha \mu \alpha \rho \varepsilon v ́ \varsigma$ albo $\Sigma \alpha \mu \alpha \rho \varepsilon i \varsigma \varsigma$ przy czym te określenia nie definiują ich zorientowania religijnego ${ }^{12}$.

Wśród wielu nazw można się spotkać w literaturze antycznej z takimi określeniami mieszkańców terenu Samarii jak m.in. Samarytanie (2 Krl 17,29), Samarianie (por. Ant. 17,69 i Bell. 1,592), Mężowie Samarytańscy (por. Ant. 18, 30), Chutejczycy (zob. Ant. 9,278-279), a także Sychemici ${ }^{13}$. H.G. Kippenberg uważał, że Samarytanie ( $\Sigma \alpha \mu \alpha \rho \varepsilon i \bar{c})$ to grupa wyznawców związana z czcią oddawaną Bogu

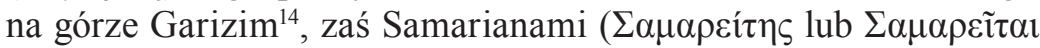
por. Ant. 17,69 i Bell. 1,592) określa się wszystkich mieszkających na terenie Samari1 ${ }^{15}$. Wobec różnorodności nazewnictwa pojawia się pytanie o proweniencję Samarytan. Bez trudu można napotkać hipotezy mówiące, że Samarytanie wyrastają z ludów pogańskich, które przejęły w pewnym stopniu kult Jedynego Boga od Izraelitów (por. w 2 Krl 17). Jednak, jak sugeruje wielu uczonych, fragment $2 \mathrm{Krl}$ 17,29 może być następstwem antypatii żydowskich względem odstępców od prawdziwego kultu jerozolimskiego zamieszkujących tereny Samarii. Stąd jego wiarygodność zdaje się być wątpliwa ${ }^{16}$. Dlatego, jak sugeruje Feldman, należałoby upatrywać korzeni ludności samarytańskiej wśród Narodu Wybranego ${ }^{17}$. Można, idąc za ciosem,

1 Tamże, s. 165.

12 Por. M. Bednarski, art. cyt., s. 38.

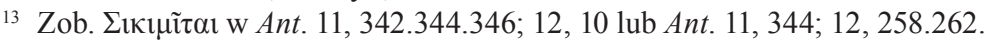

14 Por. S. Wypych, art. cyt., s. 165n.

15 Por. M. Bednarski, art. cyt., s. 38.

16 Por. W. Chrostowski, „Nic nie zostało, jak tylko samo pokolenie Judy” (2 Krl 17, 18b)-czy naprawdę? Zagłada Samarii i Królestwa Izraela oraz jej skutki, w: Collectanea Theologica 68 (1998), Warszawa 1998, s. 5-22.

${ }^{17}$ L. Feldman, Josephus Attitude toward the Samaritans. A Study in Ambivalence, w: Jewish Sect, Religious Movements and Political Parties, red. M. Mor, Omaha 1992, s. 35. 
occurs only once in the Old Testament, in 2 Kings 17:29, and is probably the translation of from the Hebrew verb רמש (šāmar), which means to watch or guard ${ }^{11}$. The name Samaritans does not carry an unambiguous designator. It can mean both the inhabitants of Samaria, i.e. pagans or followers of the Mosaic religion, or those who practised their own cult on Mount Gerizim in opposition to the cult of the God of Israel in Jerusalem. Josephus, describing the inhabitants of Samaria, uses such terms as $\Sigma \alpha \mu \alpha \rho \varepsilon v$ $\varsigma$ or $\Sigma \alpha \mu \alpha \rho \varepsilon \tilde{i}$, but these terms do not define their religious orientation ${ }^{12}$.

Among the many names one may encounter in ancient literature for the inhabitants of the Samaria area are the people of Samaria (2 Kings 17:29), Samarians/“Samareitai" (cf. Ant. 17,69 and Bell. 1.592), the Samaritans (cf. Ant. 18:30), "Chouthaioi" (see Ant. 9.278-279), as well as the Shechemites ${ }^{13}$. Kippenberg considered the Samaritans ( $\Sigma \alpha \mu \alpha \rho \varepsilon i \bar{c})$ to be the group of believers associated with the worship of God on Mount Gerizim ${ }^{14}$, while the Samarians /Samareitai ( $\Sigma \alpha \mu \alpha \rho \varepsilon i ́ \tau \eta \varsigma$ or $\Sigma \alpha \mu \alpha \rho \varepsilon i \tau \alpha \alpha$ cf. Ant. 17.69 and Bell. 1.592) are referred to all those living in Samaria ${ }^{15}$. In view of the variety of denominations, the question arises as to the provenance of the Samaritans. One can easily encounter hypotheses stating that the Samaritans grew out of the pagan tribes that to some extent took over the worship of the one God from the Israelites (cf. in 2 Kings 17). However, as many scholars have suggested, the passage in 2 Kings 17:29 may be a consequence of Jewish antipathy towards the deviants from the true Jerusalem cult living in the Samaria area. Hence, its reliability seems to be questionable ${ }^{16}$. Therefore, as Feldman suggests, the roots

11 Ibid, p. 165.

12 Cf. M. Bednarski, art. cit., p. 38.

13 See $\Sigma ı 1 \mu i \tau \alpha \iota$ in Ant. 11, 342.344.346; 12, 10 or Ant. 11, 344; 12, 258.262.

${ }_{14}$ Cf. S. Wypych, art. cit., p. 165 n.

15 Cf. M. Bednarski, art. cit., p. 38.

${ }^{16}$ Cf. W. Chrostowski, Cf. W. Chrostowski, „Only the tribe of Judah was left” (2 Kings 17:18b) - was it indeed? The annihilation of Samaria and the Kingdom of Israel and its consequences, in: Collectanea Theologica 68 (1998), Warsaw 1998, p. 5-22. 
zauważyć swoistą niekonsekwencję we Flawiuszowej ocenie kwestii pochodzenia Samarytan. Historyk izraelski, używając m.in. terminu

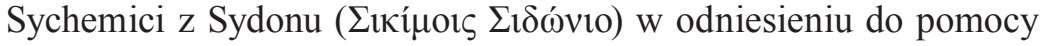
materialnej udzielonej przez Aleksandra Wielkiego przy budowie świątyni w Garizim (por. Ant. 11, 343-346), daje do zrozumienia, że owa zapomoga miała na celu podzielić synów Narodu Wybranego. Co tym samym stoi w opozycji wobec pogańskiej koncepcji proweniencji Samary $\tan ^{18}$. Jeśli idzie o początki kultu na górze Garizim trudno znaleźć spójne i wiarygodne źródła. Niewykluczone, że w pierwotnych stadiach organizacji świątyni na Garizim brali udział Fenicjanie, którzy zaadoptowali elementy kulturowe oraz religijne od Żydów ${ }^{19}$.

Inna nazwa opisująca ludność krainy Samarii z jaką można się

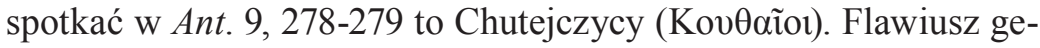
nezy Chutejczyków upatruje w czasie niewoli asyryjskiej ok. $722 \mathrm{r}$. prz.Chr., zaś samarytańskie źródła wskazują na emigrację ludności Samarii w okresie Machabeuszy do Wadi al-Kutha. Przez tę nazwę miejscowości zaczęto nazywać Samarytan Chutejczykami ${ }^{20}$. Zaś dla kontrastu warto nadmienić, iż sami Samarytanie nazywali siebie prawowitym Narodem Wybranym i stróżami autentyczności Prawa ${ }^{21}$.

Ciężko odgadnąć, który z terminów odnosił się do mieszkańców terytorium Samarii, a który do Samarytan sprawujących kult na Garizim. Przykładem tego może być opis incydentu rozrzucenia kości na obszarze Świątyni Jerozolimskiej (por. Ant. 18,29-30). Ten czyn został przypisany przez Flawiusza mężom Samarytańskim

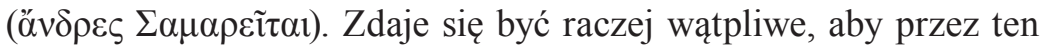
termin rozumiano ludność Samarii sprawującą kult na Garizim, chociażby z uwagi na zbieżność między Żydami i czcicielami z Samarii w kwestiach zachowywania czystości rytualnej²2. Stąd najbardziej

18 Por. M. Bednarski, art. cyt., s. 43.

19 R. Egger, Josephus Flavius und die Samaritaner. Novum Testamentum et Orbis Antiquus 4, Freiburg (Schweiz) - Göttingen 1986, s. 78n.

${ }^{20}$ Por. M. Bednarski, art. cyt., s. 45.

21 Tamże, s. 46n.

22 R. Egger, dz. cyt., s. $245 n$. 
of the Samaritan population should be found among the Chosen People ${ }^{17}$. Following this line of thought, one may note a peculiar inconsistency in Josephus' assessment of the question of the origin of the Samaritans. The Israelite historian, by using, among other things, the term Shechemites of Sidon ( $\Sigma$ เínoı $\Sigma 1 \delta \omega ́ v 10)$ in reference to the material aid given by Alexander the Great for the construction of the temple at Gerizim (cf. Ant. 11.343-346), implies that the aid was intended to divide the sons of the Chosen People. Which thus stands in opposition to the pagan conception of the provenance of the Samaritans ${ }^{18}$. Concerning the origins of the cult on Mount Gerizim, it is difficult to find consistent and reliable sources. It can be assumed that the Phoenicians were involved in the initial stages of the organization of the temple on Gerizim, and that they adopted cultural and religious elements from the Jews ${ }^{19}$.

Another name to describe the people of the land of Samaria found in Ant. 9.278-279 is Chouthaioi (KovӨaĩot). Josephus traces the origin of the Chouthaioi to the time of the Assyrian captivity around $722 \mathrm{BC}$, while Samaritan sources point to the emigration of the people of Samaria to Wadi al-Kutha during the Maccabean period. Because of the name of the place, the Samaritans came to be known as Choutaioi/Khuteans ${ }^{20}$. In contrast, the Samaritans called themselves the legitimate Chosen People and guardians of the authenticity of the Law $^{21}$.

It is difficult to guess which term referred to the inhabitants of Samaria and which to the Samaritans worshipping at Gerizim. An example is the description of the incident of the scattering of bones in the Jerusalem Temple area (cf. Ant. 18.29-30). This act was

${ }^{17}$ L. Feldman, Josephus Attitude toward the Samaritans. A Study in Ambivalence, in: Jewish Sect, Religious Movements and Political Parties, ed. by M. Mor, Omaha 1992, p. 35.

18 Cf. M. Bednarski, art. cit., p. 43.

19 R. Egger, Josephus Flavius und die Samaritaner. Novum Testamentum et Orbis Antiquus 4, Freiburg (Schweiz) - Göttingen 1986, p. 78n.

${ }^{20}$ Cf. M. Bednarski, art. cit., p. 45.

${ }^{21}$ Ibid, p. 46n. 
prawdopodobna zdaje się być hipoteza, iż sprawami owego występku była grupa Samariańskich żołnierzy o pogańskiej denominacji ${ }^{23}$. W późniejszych relacjach żydowskiego historyka odnośnie do Samarytan można zaobserwować swoiste złagodzenie dającej się wcześniej zauważyć w tekstach niechęci lub nienawiści. Przykładem jest opowiadanie o zbrojnej interwencji Piłata na górze Garizim (zob. Ant. 18, 85-89).

\section{PARABOLA O MILOSIERNYM SAMARYTANINIE W TRZECIEJ EWANGELII KANONICZNEJ}

Na szczególną uwagę przy omawianiu biblijnego obrazu Samarytan w Nowym Testamencie zasługuje parabola o Miłosiernym Samarytaninie (zob. Łk 10, 25-37). Można dostrzec w niej ogromny kontrast pomiędzy postawami kapłana i lewity, a samarytańskiego podróżnika. Doskonałymi wykonawcami Prawa, a przez to naśladowcami samego Boga, nie okazali się synowie Izraela pełniący służbę w świątyni Pana, lecz trzeci z kolei przechodzień.

Mianem kapłana וֹוכ określano w czasach patriarchów jedynie pogańskich ofiarników zajmujących się kultem. Dopiero w późniejszym okresie terminu וֹ zaczęto używać zarówno względem kapłanów Boga Izraela, jak i służących bóstwom ościennych narodów ${ }^{24}$. Pośród Narodu Wybranego w okresie patriarchów funkcje kultowe sprawowali sami patriarchowie, a następnie kiedy tworzyły się pierwsze sanktuaria pojawiali się przy nich pierwsi kapłani przeznaczeni do sprawowania kultu Boga Abrahama, Izaaka i Jakuba ${ }^{25}$. Jednakże istotne zdaje się odwołanie do postawy kapłanów, a zwłaszcza do napomnień, które Bóg kierował pod ich adresem, gdyż to pozwoli nam zrozumieć, dlaczego Jezus nie postawił ich jako wzoru postępowania wobec bliźnich.

\footnotetext{
23 Por. M. Bednarski, art. cyt., s. 57n.

24 J. Homerski, Kapłaństwo w Starym Testamencie, w: Roczniki Teologiczne 41 (1994) 1, Lublin 1994, s. 16.

25 Tamże.
} 
attributed by Josephus to the Samaritan ( $(\alpha \nu \delta \rho \varepsilon \varsigma \Sigma \alpha \mu \alpha \rho \varepsilon i \tau \alpha)$. It seems rather doubtful that by this term was meant the people of Samaria worshipping at Gerizim, not least because of the convergence between Jews and worshippers from Samaria in matters of ritual purity ${ }^{22}$. Hence, the most likely hypothesis seems to be that the perpetrators of that transgression were a group of Samarian soldiers of pagan denomination ${ }^{23}$. In the later accounts of the Jewish historian with regard to the Samaritans, one can observe a kind of softening of the dislike or hatred that could be seen earlier in the texts. An example is the story of Pilate's armed intervention on Mount Gerizim (see Ant. 18.85-89).

\section{THE PARABLE OF THE GOOD SAMARITAN IN THE THIRD GOSPEL}

Bible readers will be familiar with the parable of the "good Samaritan" in Luke 10:25-37. There one can see the great contrast between the attitudes of the priest and the Levite and the Samaritan traveller. The perfect performers of the Law, and thus imitators of God himself, were not the sons of Israel serving in the temple of the Lord, but the third passer-by.

The term priest וזהוכ referred in the time of the patriarchs only to pagan sacrificers involved in worship. It was not until later that the term והוכ was used both to refer to priests of the God of Israel and to those who served the deities of neighbouring nations ${ }^{24}$. Among the Chosen People, during the patriarchal period, the cult functions were performed by the patriarchs themselves, and then, when the first sanctuaries were being established, the first priests appeared at them to worship the God of Abraham, Isaac and Jacob ${ }^{25}$. However, it seems important to refer to the attitude of the priests, and especially

\footnotetext{
22 R. Egger, op. cit., p. 245n.

${ }^{23}$ Cf. M. Bednarski op. cit., p. 57n.

${ }^{24}$ J. Homerski, Kapłaństwo w Starym Testamencie [Priesthood in the Old Testament], in: Roczniki Teologiczne 41 (1994) 1, Lublin 1994, p. 16.

25 Ibid.
} 
Kapłani mieli być pasterzami i przewodnikami duchowymi Izraelitów, tymczasem w wielu miejscach Starego Testamentu można spotkać liczne nagany wobec stanu kapłańskiego. Prorok Ozeasz wypomina kapłanom, że prowadzą lud Boży do zguby z powodu braku nauczania, którego kapłanie nie podejmują, ponieważ sami odrzucili wiedzę, odstąpili od wskazań Tory (por. Oz 4,4-9). Przez wiedzę lub poznanie prorok rozumie nie tyle czynności intelektualne, lecz relację z Bogiem wyrażoną w otwartości i gotowości człowieka do przyjmowania miłości Boga oraz ludzkiej odpowiedzi miłością i wiernością Panu ${ }^{26}$.

Hebrajskie słowo וזהוכ wywodzi się od arabskiego słowa oznaczającego także proroka oraz widzącego ${ }^{27}$. W kontekście zachowania kapłana w przypowieści o miłosiernym Samarytaninie mamy do czynienia ze znacznym dysonansem. Kapłan dostrzegł cierpiącego,

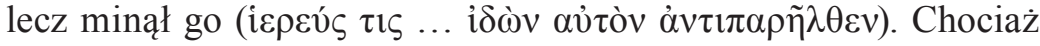
był widzącym, to jednak zachował się jak ślepy, a może co gorsza nie chciał swym przewrotnym sercem dostrzec biedaka na wpół umarłego. Można by przypuszczać, że chciał uniknąć wejścia w stan niedyspozycji do sprawowania kultu przez kontakt z krwią lub zwłokami. Jednakże kapłan schodził z Jerozolimy do Jerycha, zatem należy przypuszczać, że wracał po skończonej służbie w świątyni. Jednakże Miszna stwierdza, że zakaz dotykania umarłych nie obowiązuje, gdy zwłoki są nagie, a poszkodowany był obdarty z szat ${ }^{28}$. Co jeśli nie chodziło tu nawet o strach przed nieczystością rytualną, a jedynie o swój interes?

Jeśli idzie o drugiego przechodnia, a więc o lewitę, należy przypomnieć, że Lewici nie posiadali ziemi, lecz Pan był ich działem (Lb 18,20). Z tego powodu na Izraelitach spoczywa obowiązek troski o uposażenie lewitów (Pwt 12,12). Prawdopodobnie do czasów powrotu z Niewoli Babilońskiej nie był znany podział na kapłanów

26 M. Szmajdziński, Ideał kapłana w księdze Ozeasza, w: Verbum Vitae 17 (2010), Lublin 2010, s. 80.

27 Por. M. Rosik, Ze wzgórz Samarii, Wrocław 2005, s. 93.

28 Tamże. 
to the admonitions which God addressed to them, since this will enable the reader to understand why Jesus did not set them as a model of behaviour towards others.

Priests were supposed to be the shepherds and spiritual guides of the Israelites, yet in many places in the Old Testament we find various condemnations of the priestly state. The prophet Hosea reproaches the priests for leading God's people to perdition because of a lack of teaching, which the priests do not undertake since they themselves have rejected knowledge, have ignored the guidance of the Torah (Cf. Hosea 4:4-9). By knowledge or cognition, the prophet means not so much intellectual activities, but a relationship with God expressed in man's openness and readiness to receive God's love and human response of love and fidelity to the Lord $^{26}$.

The Hebrew word וזהוכ is derived from an Arabic word also meaning prophet and seer ${ }^{27}$. In the context of the priest's behaviour in the parable of the merciful Samaritan there is considerable dissonance.

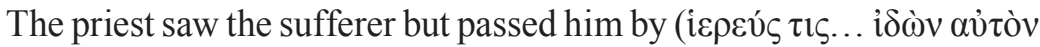
$\dot{\alpha} v \tau \imath \pi \alpha \rho \tilde{\eta} \lambda \theta \varepsilon v)$. Although he was a seer, he acted as if he were blind, or perhaps worse, he refused with his perverse heart to see the poor man half dead. One might suppose that he wanted to avoid entering into a state of indisposition for worship by contact with blood or corpses. However, as the priest was descending from Jerusalem to Jericho, it must be assumed that he was returning after completing his service in the temple. Nevertheless, the Mishnah states that the prohibition against touching the dead does not apply if the corpse is naked and the victim has been stripped of their garments ${ }^{28}$. What if it had not even been about fear of ritual impurity, but only about self-interest?

As for the second passer-by, i.e. the Levite, it should be recalled that the Levites had no inheritance in their land, but the Lord was their

${ }^{26}$ M. Szmajdziński, Ideat kaptana w księdze Ozeasza [The Ideal of a Priest in the Book of Hosea], in: Verbum Vitae 17 (2010), Lublin 2010, p. 80.

27 Cf. M. Rosik, Ze wzgórz Samarii [From the Hills of Samaria], Wrocław 2005, p. 93 .

28 Ibid. 
oraz lewitów, stąd pierwsza wzmianka biblijna wyraźnie rozdzielająca ówczesnych duchownych na kapłanów i lewitów pojawia się w księdze Ezechiela (por. Ez 44,9-31) ${ }^{29}$. Liczne wzmianki na temat powołania i zadań lewitów znajdują się w księgach Pięcioksięgu (por. Pwt 10,1-9; 17,8-13; Lb 3,5-9; 4,1-49). Do zadań lewitów należą m.in.: posługa przy kulcie (por. Pwt 10,8), pośrednictwo przy konsultacjach z Panem, udzielanie błogosławieństw, troska o przestrzeganie Prawa (por. Pwt 17,18), jak również wydawania wyroków w kwestiach spornych (por. Pwt 21,5). Po powrocie z Niewoli Babilońskiej lewici utracili prawo bezpośredniej posługi ofiarniczej, ale podczas sprawowania kultu zajmowali się śpiewem, poza tym mieli pieczę nad bramami świątynnymi, przy których pilnowali porządku ${ }^{30}$. Zamieszkiwali w Jerozolimie lub w dalszych miastach Izraela, często pełnili posługi w synagogach, zajmowali się nauczaniem Tory i sądownictwem, a zwłaszcza przepisywaniem świętych tekstów oraz dokumentów o charakterze prawnym ${ }^{31}$.

Lewita podobnie jak kapłan znał Boże Prawo i wiedział, co jest miłe w oczach Pana. Jednakże również on minął człowieka w potrze-

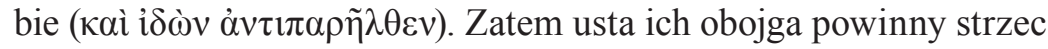
wiedzy (por. M1 2,7), aby relacja z Panem uzdalniała ich do niesienia miłosierdzia braciom w potrzebie ${ }^{32}$. Tak więc adekwatnym może się okazać stwierdzenie A. Pronzato, że droga między Jerozolimą, a Jerychem wciąż pozostaje przeklęta nie przez fakt licznych przestępstw, działalności zbójców, lecz przez pomijanie, przymuszanie serca do obojętności i brak miłości względem Boga i bliźniego ${ }^{33}$. Właśnie taką skamieniałość serc przechodniów wracających z Miasta Pokoju demaskuje Chrystus w swej przypowieści. R. Cantalamessa, komentując postawę ówczesnych duchowych przewodników, wskazuje na

29 Por. D. Dziadosz, Lewici i kapłani w księdze Powtórzonego Prawa, w: Verbum Vitae 17 (2010), Lublin 2010, s. 44n.

30 Por. M. Rosik, dz. cyt., s. $97 \mathrm{n}$.

31 Tamże.

32 Por. D. Dogondke, Charakter deuteronomistyczny Księi Malachiasza. Teologiczne implikacje intertekstualnej analizy biblijnej, Warszawa 2013, s. 110n.

33 Por. A. Pronzato, Śladami Samarytanina, Kraków 2016, s. 16 n. 
share and their inheritance (Numbers 18:20). It is therefore incumbent upon the Israelites to take care of the emoluments of the Levites (Deuteronomy 12:12). The division between priests and Levites was probably not known until the time of the return from the Babylonian Captivity, hence the first biblical reference clearly separating the clergy of that time into priests and Levites appears in Ezekiel 44:9-3129. Numerous references to the calling and tasks of the Levites are found in the books of the Pentateuch (Cf. Deuteronomy 10:1-9; 17:8-13; Numbers 3:5-9; 4:1-49). The tasks of the Levites include ministering and pronouncing blessings in Lord's name (Cf. Deuteronomy 10:8), mediating at consultations with the Lord, giving blessings, taking care of the observance of the Law (Cf. Deuteronomy 17:18), as well as deciding all cases of dispute (Cf. Deuteronomy 21:5). After the return from the Babylonian Captivity, the Levites lost the right of direct sacrificial service, but during worship they sang, and they were in charge of the temple gates, at which they kept order ${ }^{30}$. They resided in Jerusalem or further afield in the cities of Israel, often ministered in synagogues, were involved in Torah teaching and judiciary, and especially transcribed sacred texts and legal documents ${ }^{31}$.

The Levite like the priest knew God's Law and knew what was pleasing in the sight of the Lord. However, he too passed by a man

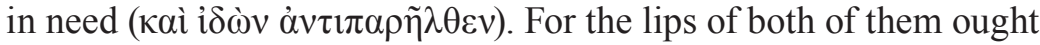
to preserve knowledge (Cf. Malachi 2:7), so that a relationship with the Lord would enable them to bring mercy to brothers in need ${ }^{32}$. Therefore, Pronzato's statement that the road between Jerusalem and Jericho is still cursed not by the numerous crimes, the activities

29 Cf. D. Dziadosz, Lewici i kapłani w księdze Powtórzonego Prawa [Levites and Priests in the Book of Deuteronomy], in: Verbum Vitae 17 (2010), Lublin 2010, p. 44 n.

${ }^{30}$ Cf. M. Rosik, op. cit., p. 97n.

31 Ibid.

32 Cf. D. Dogondke, Charakter deuteronomistyczny Księgi Malachiasza. Teologiczne implikacje intertekstualnej analizy biblijnej [The Deuteronomistic Character of the Book of Malachi. Theological Implications of Intertextual Biblical Analysis], Warsaw 2013, p. 110n. 
brak zrozumienia istoty Prawa. Właściwie zinterpretowana sprawiedliwość w tym wypadku, wypełniłaby się ze złamania przepisów zachowania czystości rytualnej, aby pomóc rannemu ${ }^{34}$.

Zapewne odbiorca Jezusowej przypowieści spodziewał się, że jako trzeci w narrację zostanie wpleciony Izraelita, lecz niespodziewanie pojawia się zaskakująca postać. Jezus w swojej przypowieści pominął istniejące w żydowskim społeczeństwie konwenanse przez sam fakt wprowadzenia w parabolę postaci Samarytanina. Jednakże przedstawienie trzeciego w kolejności podróżnika jako wzoru w wypełnianiu poleceń Boga Izraela to dla Żydów, mówiąc eufemistycznie, swoisty nietakt. Okazuje się jednak, że najbardziej niekoszerny w znaczeniu religijnym stał się najbardziej podobnym do Boga przez swoje czyny.

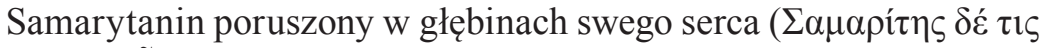

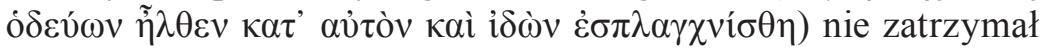
się na poziomie emocji, ale konkretnym działaniem pomógł temu, w którym dostrzegł bliźniego. Samarytanin wzruszył się głęboko widokiem na wpół umarłego człowieka (por. Łk 10,33) i nie poprzestał jedynie na poziomie afektywnym. Można powiedzieć, iż miał wrażliwe oczy serca, które pozwoliły mu dostrzec w pobitym człowieku bliźniego. Za I. Gargano dostrzegamy, że słowo Jezusa ma za zadanie otwierać oczy i uzmysławiać ludziom, iż Stwórca patrzy zupełnie inaczej na otaczającą nas rzeczywistośćc ${ }^{35}$. Bóg sam mówi o sobie wobec proroka Samuela: ,nie tak bowiem człowiek widzi, jak widzi Bóg, bo człowiek patrzy na to, co widoczne dla oczu, Pan natomiast patrzy na serce" (por. 1Sm 16,7). Warto podkreślić, że nie znajdujemy żadnych przesłanek w przypowieści jakoby cudzoziemca łączyły z rannym więzy krwi, wspólnota majątkowa lub chociażby kult na górze Garizim. Skoro tak, to zapewne zatrzymał się dlatego, że zobaczył w ofierze zbójców po prostu potrzebującego człowieka, który jak każdy inny nosi w sobie obraz i podobieństwo Stwórcy. Ów przechodzień zaryzykował, stracił czas i dobra, aby pomóc drugiemu

34 R. Cantalamessa, Oblicza miłosierdzia Boga i człowieka, Częstochowa 2016, s. $133-138$.

35 Por. I. Gargano, Miłosierni jak ojciec, ZFD 47 (2017), Kraków 2017, s. 24. 
of the robbers, but by the omission, by forcing the heart to indifference and lack of love towards God and neighbour, may be appropriate ${ }^{33}$. It is precisely this fossilisation of the hearts of passers-by returning from the City of Peace that Christ exposes in his parable. Cantalamessa, commenting on the attitude of the spiritual guides of that time, points to their lack of understanding of the essence of the Law. Properly interpreted justice, in this case, would have been fulfilled by breaking the rules of ritual purity in order to help the wounded ${ }^{34}$.

Probably the addressee of Jesus' parable expected an Israelite to be woven into the narrative as the third, but a surprising figure unexpectedly appears. In his parable, Jesus disregarded existing conventions in Jewish society by the very fact of introducing the figure of the Samaritan into the parable. However, the presentation of the third-ranked traveller as a model in obeying the commands of the God of Israel is, euphemistically speaking, a kind of gaffe for the Jews. It turns out, however, that the most unkosher in a religious sense became the most God-like by his actions. The Samaritan moved

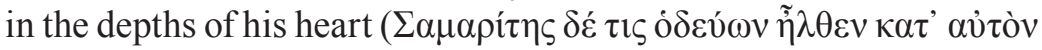

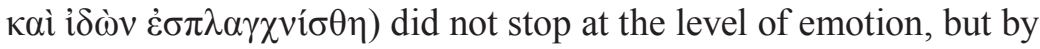
a specific action helped the one in whom he perceived a neighbour. The Samaritan was deeply moved by the sight of the half-dead man and took pity on him (Cf. Lk 10:33) and did not stop only at the affective level. It can be said that he had sensitive eyes of the heart that allowed him to see his neighbour in the beaten man. Following Gargano, we see that the word of Jesus has the task of opening people's eyes and making them aware that the Creator looks at the reality around us in a completely different way ${ }^{35}$. God speaks of himself to the prophet Samuel: "The Lord does not look at the things people look at. People

33 Cf. A. Pronzato, In the Footsteps of the Samaritan [Sulle tracce del samaritano. Pellegrinaggio al santuario dell'uomo], Polish version: Kraków 2016, p. 16n.

34 R. Cantalamessa, The Gaze of Mercy: A Commentary on Divine and Human Mercy [Il volto della misericordia. Piccolo trattato sulla divina e sulla umana Misericordia], Polish version: Częstochowa 2016, pp. 133-138.

${ }_{35}$ Cf. I. Gargano, Miłosierni jak ojciec [Merciful like Father], ZFD 47 (2017), Kraków 2017, p. 24. 
człowiekowi. Można by powiedzieć językiem Jana Pawła II, że Samarytanin miał wyobraźnię miłosierdzia ${ }^{36}$, która nie pozwoliła minąć poranionego biedaka.

Jeśliby odwołać się do tradycji pierwotnego Kościoła, należałoby odczytać przypowieść o Miłosiernym Samarytaninie przez pryzmat alegoryczny. Jako parabolę o ludzkości reprezentowanej przez praojca Adama. Pierwszy człowiek zmuszony przez grzech do opuszczenia raju schodzi na świat i zostaje napadnięty przez szatana, który odziera go z dóbr duchowych, a następnie kaleczy wadami i niedoskonałościami. Rannemu nie pomagają nawet przepisy Starego Testamentu, co zostało przedstawione w przypowieści jako pominięcie go przez kapłana i lewitę. Dopiero Wcielony Logos ukryty w paraboli pod postacią Samarytanina obmywa jego rany swoją krwią i miłosierdziem Tego, który Go posłał, a więc Ojca, czego symbolem są oliwa i wino. Potem zaprowadza go do gospody, która jest obrazem wspólnoty Kościoła $^{37}$.

Z kolei św. Ambroży z Mediolanu intepretuje tę parabolę, rozpoczynając od symboliki Jerycha jako obrazu ziemskiego padołu, na który Adam musiał zejść z powodu swego nieposłuszeństwa. Wpadając w grzechy, został pozbawiony odzienia łaski, a następnie jako nagi został śmiertelnie zraniony. Niechybnie umarłby, gdyby nie wydarzenie Jezusa Chrystusa, który niczym Samarytanin okazał się bliźnim rodzaju ludzkiego. Podobnym we wszystkim z wyjątkiem grzechu, solidarnym w cierpieniu, dźwigającym winy nas wszystkich, mężem boleści zeszpeconym tak, iż mieliśmy go za nic (por. Iz 53). Chrystus zastosował liczne medykamenty, aby doprowadzić człowieka do zdrowia. Bożym lekiem, jak zauważa św. Ambroży, jest mowa Chrystusa, którego słowa obwiązują nasze rany. Zbawiciel zaprowadził rannego do gospody i zajmował się ludzkością, lecz nazajutrz musiał opuścić gospodę, co zostało przez św. Ambrożego zinterpretowane jako symbol zmartwychwstania Pańskiego. Dwoma denarami są

36 Por. Jan Paweł II, List Apostolski Novo millennio ineunte, Watykan 2001, nr 50.

37 Por. S. Wailes, Medieval allegories of Jesus' parables, Berkeley 1987, s. 210n. 
look at the outward appearance, but the Lord looks at the heart." (Cf. $1 \mathrm{Sm} \mathrm{16,7).} \mathrm{It} \mathrm{is} \mathrm{worth} \mathrm{noting} \mathrm{that} \mathrm{we} \mathrm{do} \mathrm{not} \mathrm{find} \mathrm{any} \mathrm{indication} \mathrm{in}$ the parable that the foreigner was connected to the wounded man by blood ties, community of property or even worship on Mount Gerizim. If so, he probably stopped because he saw in the robbers' victim simply a man in need, who, like everyone else, bears within himself the image and likeness of the Creator. This passer-by took a risk, wasted his time and goods in order to help another human being. We could say in the language of John Paul II that the Samaritan had a picture of mercy ${ }^{36}$, which did not allow the wounded poor man to pass by.

If one were to refer to the tradition of the early Church, one would have to read the parable of the Good Samaritan through an allegorical prism. As a parable about humanity represented by the forefather Adam. The first man, forced by sin to leave paradise, descends into the world and is attacked by Satan, who strips him of his spiritual goods and then cripples him with vices and imperfections. The wounded man is not even helped by the rules of the Old Testament, which is depicted in the parable as being overlooked by the priest and the Levite. Only the Incarnate Logos, hidden in the parable under the figure of the Samaritan, washes his wounds with his blood and with the mercy of the One who sent him, that is, the Father, symbolised by the oil and wine. Then he leads him to an inn, which is an image of the community of the Church ${ }^{37}$.

St. Ambrose of Milan, on the other hand, interprets this parable, beginning with the symbolism of Jericho as an image of the earthly paddock to which Adam had to descend because of his disobedience. Falling into sins, he was deprived of the garment of grace, and then as naked he was mortally wounded. He would inevitably have died had it not been for the event of Jesus Christ, who, like the Samaritan, proved to be a fellow human being. Like him in all things but sin, 50 .

${ }^{36}$ Cf. John Paul II, Apostolic Letter Novo millennio ineunte, Vatican 2001, No.

${ }^{37}$ Cf. S. Wailes, Medieval Allegories of Jesus' Parables, Berkeley 1987, p. 210 n. 
cztery Ewangelie, zaś gospodarzami Apostołowie, którym to gospodarzom Pan wynagrodzi za ich miłość pasterską w dniu sądu ${ }^{38}$. Podobnie św. Augustyn z Hippony dostrzega w pobitym człowieku Adama skrzywdzonego przez szatana i jego aniołów, zaś Miłosierny Samarytanin, czyli sam Jezus leczy ludzkość sakramentami, czego symbolem są oliwa oraz wino. Człowiek dzięki sakramentom otwiera się na łaskę wiary, która prowadzi do uzdrowienia w gospodzie, czyli we wspólnocie Kościoła, gdzie gospodarzami są pasterze ${ }^{39}$.

Za ojcami Kościoła należy dostrzec pod postacią Miłosiernego Samarytanina samego Chrystusa, który nie tylko jest Zbawcą ludzkości, lecz także objawieniem miłości i miłosierdzia Ojca ${ }^{40}$. Stąd miłosierdzie zostało przez papieża Franciszka zdefiniowane jako droga, na której grzeszny człowiek może spotkać Boga i otworzyć się na nadzieję bezwarunkowej miłości Ojca, która czeka pomimo ludzkich grzechów ${ }^{41}$. Zadaniem wspólnoty Łukaszowej, jak również współczesnego Kościoła, jest naśladowanie Chrystusa w konkretnej miłości wyrażonej względem bliźnich, którymi są wszyscy ludzie. Przypowieść o Miłosiernym Samarytaninie uczy, że programem działania chrześcijan winno być dostrzeganie potrzeb miłości i konkretne pomocowe działanie ${ }^{42}$.

\section{MILOSIERNY SAMARYTANIN WZOREM WSPÓLCZUCIA}

Na uwagę zasługuje fakt posłużenia się przez Łukasza czasownikiem z rodziny $\sigma \pi \lambda \alpha ́ \gamma \chi \chi v 0 v-\sigma \pi \lambda \alpha \gamma \chi v i ́ \zeta o \mu \alpha \iota \mathrm{w}$ opisie wzruszenia samarytańskiego przechodnia. Ów czasownik jest słowem określającym uczucie ulitowania i współczucia jako delikatne i bardzo intymne, ale

38 Por. Św. Ambroży, Wykład Ewangelii według św. Łukasza, tłum. W Szołdrski, Warszawa 1977, s. 279-283.

39 Por. R. Stein, The interpretation of the Parable of the Good Samaritan, Grand Rapids Michingan 1978, s. 278-295.

40 Jan Paweł II, Dives in Misericordia, Watykan 1980, nr 1.

${ }^{41}$ Franciszek, Bulla Misericordiae Vultus, Watykan 2015.

${ }^{42}$ Benedykt XVI, Deus caritas est, Watykan 2005, nr 31. 
a man of suffering, and familiar with pain, bearing the guilt of us all, a man of sorrows so despised, and we held him in low esteem (Cf. Is 53). Christ used numerous medicines to bring man to health. God's medicine, as St. Ambrose notes, is the speech of Christ, whose words bind up our wounds. The Saviour led the wounded man to an inn and attended to humanity, but the next day had to leave the inn, which was interpreted by St Ambrose as a symbol of the Lord's resurrection. The two denarii are the four Gospels, and the hosts are the Apostles, whom the Lord will reward for their shepherding love on the day of judgement ${ }^{38}$. Similarly, St. Augustine of Hippo sees in the beaten man Adam harmed by Satan and his angels, while the Merciful Samaritan, Jesus himself, heals humanity with the sacraments, symbolized by oil and wine. Through the sacraments, man opens himself up to the grace of faith, which leads to healing in the inn, that is, in the community of the Church, where the hosts are shepherds ${ }^{39}$.

Following the Fathers of the Church, it is necessary to perceive Christ Himself under the figure of the Merciful Samaritan, who is not only the Saviour of humanity, but also the revelation of the Father's love and mercy ${ }^{40}$. Hence, mercy as defined by Pope Francis is the path on which sinful man can meet God and open himself to the hope of the Father's unconditional love, which awaits despite human sins ${ }^{41}$. The task of the community of Luke, as well as of the contemporary Church, is to imitate Christ in real love expressed towards our neighbours, who are all people. The parable of the Good Samaritan teaches that the programme of action of Christians should be to recognise the needs of love and provide real help ${ }^{42}$.

38 Cf. St. Ambrose, An Exposition of the Gospel According to Luke, Polish transl. W Szołdrski, Warsaw 1977, pp. 279-283.

39 Cf. R. Stein, The Interpretation of the Parable of the Good Samaritan, Grand Rapids Michigan 1978, pp. 278-295.

40 Jan Paweł II, Dives in Misericordia, Vatican 1980, no. 1.

${ }^{41}$ Francis, Bulla Misericordiae Vultus, Vatican 2015.

42 Benedict XVI, Deus caritas est, Vatican 2005, no. 31. 
również jako takie, które jest pobudką do dobrego czynu ${ }^{43}$. Czasownik $\sigma \pi \lambda \alpha \gamma \chi v i \zeta \zeta o \mu \alpha \iota$ występuje dwanaście razy w Nowym Testamencie ${ }^{44}$, z czego trzy razy w Ewangelii wg św. Łukasza (Łk 7,13; 10,33; 15,20). Czasownik ten, wyrażający fizyczne poruszenie wnętrzności na widok czyjejś niedoli, przejęcie się do głębi czyimś nieszczęściem, ma za swój podmiot w Ewangeliach niemal wyłącznie Jezusa. Przez to reakcja Samarytanina z przypowieści może być w istocie naśladowaniem współczucia i solidarności, jakie prezentuje Jezus wobec ludzkiej biedy i tragedii ${ }^{45}$.

Czasownik ten pochodzi od terminu $\sigma \pi \lambda \alpha ́ \gamma \chi v o v$, który został zastosowany w chrześcijańskim kanonie Starego Testamentu jako określenie wnętrzności por. (2 Mch 6,8; Prz 26,22) lub serca (Prz $12,10)$ albo wnętrza człowieka (Syr 33,5), a także jako symbol litości (Syr 30,7; Mdr 10,5). W Septuagincie poza kanonem pojawia się także trzykrotne zastosowanie tego terminu odnośnie do wnętrzności ciała (4 Mch 5,30; 10,8; 11,19;) oraz jako określenie siedliska miłości w sensie uczuciowym (4 Mch 14,13; 15,23; 15,29) ${ }^{46}$. W klasycznej

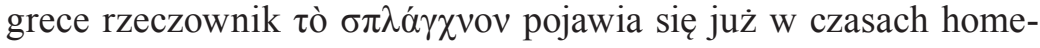
ryckich i prawie zawsze występuje w liczbie mnogiej, określając wnętrzności zwierząt ofiarnych ${ }^{47}$, od V w. czasem odnosi się go do ludzkich wnętrzności. Tak więc znaczenie bazy semantycznej $\sigma \pi \lambda \alpha \dot{\gamma} \chi v 0 v-\sigma \pi \lambda \alpha \gamma \chi v i \zeta{ }_{0} \mu \alpha \iota \mathrm{w}$ Septuagincie kształtowało się pod wpływem środowiska hellenistycznego, ale zostało wzbogacone o cechę miłosierdzia ${ }^{48}$.

Natomiast w Nowym Testamencie rzeczownik $\sigma \pi \lambda \alpha \dot{\gamma} \chi v \alpha$ wy-

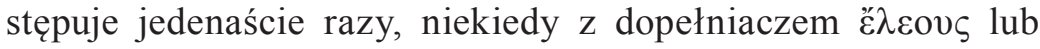

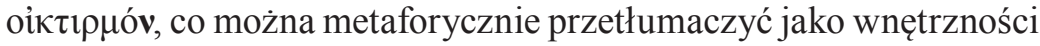

\footnotetext{
43 Tamże, nr 24.

${ }^{44}$ F. Mickiewicz, Ewangelia wg św. Łukasza, w: NKB NT III/1, Częstochowa 2011, s. 380 .

45 W. Pikor, Przypowieści Jezusa. Narracyjny klucz lektury, Kielce 2011, s. 134.

${ }^{46}$ Por. H. Koster, $\boldsymbol{\sigma} \pi \lambda \boldsymbol{\lambda} \boldsymbol{\alpha} \gamma \chi \boldsymbol{v} \mathbf{0 v}, \mathrm{w}:$ TDNT vol. VII, s. 550n.

47 Tamże, s. 548.

48 Por. J. Czerski, Nowotestamentalna terminologia miłosierdzia, RBL 40 (1987) 1, Lublin 1987, s. 25n.
} 


\section{SAMARITAN MODEL OF COMPASSION}

It is noteworthy that Luke uses a verb from the family $\sigma \pi \lambda \alpha \gamma^{\prime} \chi v o v-$ $\sigma \pi \lambda \alpha \gamma \chi v i{ }^{\prime} \zeta{ }_{0} \alpha \iota$ in describing the emotion of the Samaritan passer-by. The verb is a word that describes feelings of pity and compassion as delicate and very intimate, but also as a stimulus to good deeds ${ }^{43}$. The verb $\sigma \pi \lambda \alpha \gamma \chi v i$ 'o $\mu \alpha$ occurs twelve times in the New Testament ${ }^{44}$, of which three times in The Gospel According to Luke (Luke 7:13; $10: 33 ; 15: 20)$. In the Gospels, this verb, which expresses the physical stirring of the heart at the sight of someone's misfortune, a deep concern for someone's misfortune, has as its subject almost exclusively Jesus. Thus, the Samaritan's reaction in the parable may in fact be an imitation of the compassion and solidarity Jesus shows towards human misery and tragedy ${ }^{45}$.

The verb is derived from the term $\sigma \pi \lambda \alpha \gamma_{\gamma} \chi v o v$, which was used in the Christian canon of the Old Testament to denote the inmost parts of the Cf. (2 Maccabees 6:8; Proverbs 26:22) or heart (Proverbs 12:10) or the interior of a person (Sirach 33:5), and also as a symbol of compassion (Sirach 30:7; Wisdom 10:5). The Septuagint also has three uses of the term outside the canon to refer to the entrails (4 Maccabees $5: 30 ; 10: 8 ; 11: 19 ;$ ) and as a term for the habitat of love, i.e. an emotion felt in the inmost parts (4 Maccabees 14:13; 15:23; $15: 29)^{46}$. In classical Greek, the noun $\tau$ ò $\sigma \pi \lambda \alpha \dot{\alpha} \chi$ vov appears as early as Homeric times and almost always occurs in the plural, denoting the entrails of sacrificial animals ${ }^{47}$, from the 5th century onwards it occasionally refers to human entrails. Thus the meaning of the semantic base $\sigma \pi \lambda \alpha \gamma \chi v o v-\sigma \pi \lambda \alpha \gamma \chi v i \zeta o \mu \alpha \iota$ in the Septuagint

\footnotetext{
43 Ibid, no. 24.

44 F. Mickiewicz, The Gospel According to Luke, in: NKB NT III/1, Czestochowa 2011, p. 380.

45 W. Pikor, Przypowieści Jezusa. Narracyjny klucz lektury [Parables of Jesus. Narrative Key to Reading], Kielce 2011, p. 134

${ }^{46}$ Cf. H. Koster, $\sigma \pi \lambda \boldsymbol{\alpha} \gamma \gamma \chi \mathbf{v o v}$, in: TDNT vol. VII, p. 550n.

47 Ibid, p. 548.
} 
miłosierdzia, czyli serdeczną litość, serdeczne miłosierdzie. Czasownik $\sigma \pi \lambda \alpha \gamma \chi v i \zeta o \mu \alpha \iota \mathrm{w}$ różnych swoich formach występuje w Ewangelii wg św. Mateusza (Mt 9,36; 14,14; 15,32; 18,27; 20,34) oraz św. Marka (Mk 1,41; 6,34; 8,2; 9,22), a także we wcześniej wskazanych perykopach trzeciej Ewangelii kanonicznej. We wszystkich perykopach u synoptyków czasownik został użyty jako opis użalenia się Jezusa nad ludem albo litości okazanej przez Pana lub podanej za wzór odniesienia się do drugiego człowieka.

Termin $\sigma \pi \lambda \alpha \gamma \chi v i ́ \zeta o \mu \alpha \iota$ odniesiony do Jezusa ma znaczenie mesjańskie ${ }^{49}$. Chrystus przyszedł, aby obwoływać rok łaski od Pana i swoje przepowiadanie potwierdzał niezwykłymi czynami, które sprawiały, że ludzie zewsząd przychodzili do Niego. Jego mesjańskie posłannictwo było zaadresowane szczególnie ku ubogim, maluczkim, chorym. Dlatego jego litość powodowały ludzkie słabości i biedy, takie jak osamotnienie (Mt 9,36), głód (Mk 8,2), rozmaite niedomagania i schorzenia (Mt 14,14; 15,32; Mk 6,34), czy śmierć (Łk 7,13).

Ewangelia Łukaszowa stosuje $\sigma \pi \lambda \alpha \gamma \chi v i ́ \zeta o \mu \alpha$ aby ukazać głębokie poruszenie się serca samego Jezusa na widok ludzkiej niedoli (Łk 7,13) oraz wzruszenie Miłosiernego Ojca (Łk 15,20). Odczytanie użycia czasownika $\sigma \pi \lambda \alpha \gamma \chi v i \zeta \zeta \mu_{\alpha} \mathrm{w}$ kontekście powyższych perykop synoptycznych pozwala zauważyć, że nie opisuje on jedynie poruszenia czysto emocjonalnego, lecz także wypływające z niego konkretne miłosierne czyny ${ }^{50}$, takie jak: nauczanie, uzdrowienie, egzorcyzm, przebaczenie czy nawet wskrzeszenie $\mathrm{z}$ martwych ${ }^{51}$. Dokładnie w taki sam sposób zachował się przedstawiony przez Jezusa w paraboli miłosierny Samarytanin. Mimo że nie oddaje on czci Bogu w Jerozolimie i pewnie nie miał tyle okazji do przebywania w kręgach związanych z sacrum co kapłan i lewita, jednak jego czyny są dużo bliższe woli Tego, który uświęca wszystko na wszelki sposób (por. Ef 1, 23). Dlatego komentując przywołaną perykopę, w swojej encyklice Fratelli tutti papież Franciszek napisał, iż: ,„paradoks polega

\footnotetext{
49 Por. N. Walter, EWNT III, Stuttgart 1983, s. 633n.

${ }^{50}$ Por. J. Czerski, art. cyt., s. 25.

51 Tamże, s. 26.
} 
was shaped by the influence of the Hellenistic environment, but was enriched by the feature of mercy ${ }^{48}$.

In the New Testament, on the other hand, the noun $\sigma \pi \lambda \alpha \dot{\gamma} \chi \nu \alpha$ occurs eleven times, sometimes in the genitive case of है $\lambda \varepsilon$ cov $\varsigma$ or

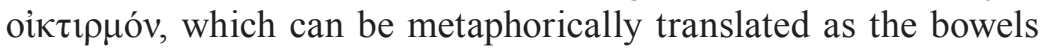
of mercy, or heartfelt compassion, heartfelt compassion. The verb $\sigma \pi \lambda \alpha \gamma \chi v i \zeta o \mu \alpha \mathrm{r}$ in its various forms occurs in The Gospels According to Matthew (Mt 9:36; 14:14; 15:32; 18:27; 20:34) and St Mark (Mk 1:41; $6: 34 ; 8: 2 ; 9: 22$ ), as well as in the previously indicated pericopes of the third Gospel. In all the pericopes in the synoptics the verb is used as a description of Jesus' pity for the people or of the pity shown by the Lord or given as a model for relating to another human being.

The term $\sigma \pi \lambda \alpha \gamma \chi v i \zeta o \mu \alpha$ applied to Jesus has a messianic meaning ${ }^{49}$. Christ came to proclaim a year of grace from the Lord and he confirmed his proclamation with extraordinary deeds which brought people from everywhere to him. His messianic mission was addressed especially to the poor, the little ones, and the sick. That is why his compassion was provoked by human weaknesses and poverty, such as loneliness (Mt 9:36), hunger (Mk 8:2), various infirmities and illnesses (Mt 14:14; 15:32; Mk 6:34), or death ( $\operatorname{Lk} 7: 13)$.

The Gospel According to Luke uses $\sigma \pi \lambda \alpha \gamma \chi v i \zeta o \mu \alpha$ to show the deep stirring of Jesus' own heart at the sight of human affliction (Lk 7:13) and the emotion of the father filled with compassion (Lk 15:20). A reading of the use of the verb $\sigma \pi \lambda \alpha \gamma \chi v i \zeta o \mu \alpha 1$ in the context of the above synoptic pericopes reveals that it does not merely describe a purely emotional emotion, but also specific acts of mercy which flow from it ${ }^{50}$, such as teaching, healing, exorcism, forgiveness or even raising from the dead ${ }^{51}$. The merciful Samaritan depicted by Jesus in the parable behaved in exactly the same way.

48 Cf. J. Czerski, Nowotestamentalna terminologia mitosierdzia [New Testament Terminology of Mercy], RBL 40 (1987) 1, Lublin 1987, p. 25n

49 Cf. N. Walter, EWNT III, Stuttgart 1983, p. 633n.

${ }^{50}$ Cf. J. Czerski, art. cit., p. 25.

51 Ibid, p. 26. 
na tym, że niekiedy ci, którzy deklarują się jako niewierzący, mogą żyć wolą Bożą lepiej niż osoby wierzące"s2.

\section{EWOLUUJĄCY OBRAZ SAMARYTAŃSKI W UJECCIU TRZECIEJ EWANGELII KANONICZNEJ}

Jeśli idzie w ogóle o Łukaszowe podejście do Samarytan, to możemy obserwować swoistą ewolucję ich obrazu w trzeciej Ewangelii kanonicznej. W opisie pierwszej sekcji podróży Jezusa do Jerozolimy, którą relacjonuje autor Dzieła Łukaszowego znajduje się opis nieprzychylności ze strony mieszkańców Samarii wobec Nazarejczka pielgrzymującego do świętego dla Żydów Miasta Pokoju. Na uwagę zasługuje fakt, iż Jezus nie stroni od ziem samarytańskich, wędrując w kierunku Jeruzalem ${ }^{53}$. Można dostrzec pewną analogię odrzucenia pomiędzy Chrystusową inauguracją ewangelizacji Galilei (por. $Ł k 4,14-30$ ) oraz rozpoczęciem podróży do Jeruzalem (por. Łk 9,51$56)^{54}$. Chrystus posyła swoich uczniów z poleceniem zadbania o miejsce, w którym mogliby się zatrzymać na terytorium Samarii. Jednak

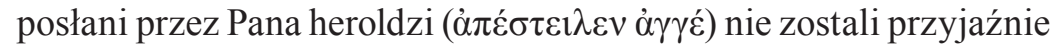
przyjęci przez miejscową ludność, nie tyle z uwagi na przynależność narodową Jezusa, lecz na cel Jego podróży ${ }^{55}$. Widzimy zatem w tej perykopie aspekt kultowy wyrażonej wobec Chrystusa i Jego uczniów nieżyczliwości. Jak zauważa S. Fausi, być może z powodu żydowskiej pogardy i odtrącenia samarytańskich chęci pomocy przy odbudowie Świątyni po powrocie z niewoli babilońskiej nie przyjmują Wykluczonego $^{56}$. Mieszkańcy owej wioski nie uszanowali Pielgrzyma i Jego towarzyszy. Jak się zdaje wspólną biedą zarówno Żydów, czcicieli związanych z górą Garizim, a także pogan jest nieprzyjęcie Pana,

${ }^{52}$ Franciszek, Encyklika Fratelli tutii, dz. cyt., nr 74.

${ }_{53}$ Por. J. Green, The New International Commentary on The New Testament, Michigan 1997, s. 304n.

${ }_{54}$ Por. F. Mickiewicz, Ewangelia wg św. Lukasza, s. 519.

55 Tamże, s. 521n.

${ }^{56}$ Por. S. Fausti, Wspólnota czyta Ewangelię wg św. Łukasza, Częstochowa 2006, s. 376. 
Even though he does not worship God in Jerusalem and probably did not have as many opportunities to be in circles related to the sacrum as the priest and the Levite, his actions are much closer to the will of the One who sanctifies everything in every way (Cf. Eph 1:23). That is why, commenting on the above-mentioned pericope, in his encyclical Fratelli tutti, Pope Francis writes that: "Paradoxically, those who claim to be unbelievers can sometimes put God's will into practice better than believers." 52

\section{EVOLVING PICTURE OF THE SAMARITANS AS SEEN IN THE THIRD GOSPEL}

As far as Luke's approach to the Samaritans in general is concerned, one can observe a kind of evolution of their picture in the third Gospel. In the description of the first section of Jesus' journey to Jerusalem, which is reported by the author of the Book of Luke, there is a description of hostility on the part of the inhabitants of Samaria towards the Nazarene on his pilgrimage to the City of Peace, sacred for the Jews. It is noteworthy that when Jesus travels towards Jerusalem, he does not avoid the Samaritan lands ${ }^{53}$. One can see a certain analogy of rejection between Christ's inauguration of the evangelization of Galilee (Cf. Lk. 4:14-30) and the beginning of the journey to Jerusalem (Cf. Lk. 9:51-56) ${ }^{54}$. Christ sends his disciples with the command to take care of a place where they could stay in the territory of Samaria. However, the heralds ( $\dot{\alpha} \pi \varepsilon \dot{\varepsilon} \sigma \varepsilon 1 \lambda \varepsilon v$ $\dot{\alpha} \gamma \gamma \dot{\varepsilon})$ sent by the Lord are not welcomed by the local people, not so much because of Jesus' nationality, but because of the purpose of his journey ${ }^{55}$. We thus see in this pericope the cultic aspect of the unkindness expressed towards Christ and his disciples. As Fausi

52 Francis, Encyclical Letter Fratelli tutii, n. 74.

${ }_{33}$ Cf. J. Green, The New International Commentary on The New Testament, Michigan 1997, p. 304n.

${ }^{54}$ Cf. F. Mickiewicz, The Gospel According to Luke, p. 519.

55 Ibid, p. 521n. 
który przyszedł szukać i ocalić to, co zginęło (por. Łk 19,10), lecz nie znalazł miejsca, gdzie byłoby Mu dane skłonić głowę (por. Łk 9,58) ${ }^{57}$.

Drugą wzmiankę dotyczącą Samarytan, a także kolejny etap ewolucji Łukaszowego stosunku wobec nich, znajdujemy w omówionej szerzej we wcześniejszych podpunktach perykopie o Miłosiernym Samarytaninie. Hagiograf namalował przed oczami czytelników zupełnie odmienny od pierwszego obraz ludu związanego z kultem na Garizim. Chociaż paraboliczny trzeci przechodzień nie czcił Boga w sposób koszerny dla synów Narodu Wybranego, to jednak wypełnił o wiele bardziej doskonale wskazania Boże niż Żydzi. Jezus, opowiadając tę przypowieść, dał odpowiedź na pytanie uczonego w Prawie o to, kogo należy nazwać mianem bliźniego. Jezusowa parabola rozszerza tożsamość bliźniego na wszystkich ludzi, a szczególnie na braci $w$ potrzebie ${ }^{58}$. Jednakże owa perykopa pokazuje także, iż pojęcie prawdziwego czciciela Boga zostaje rozciągnięte na wszystkich, którzy jak ów nieczysty, lecz miłosierny przechodzień kierują się w codzienności przykazaniem miłości Boga i bliźniego.

Należy zwrócić uwagę także na perykopę o dziesięciu trędowatych (por. Łk 17, 11-19), w której można dostrzec szczyt ewolucji samarytańskiego obrazu w trzeciej Ewangelii kanonicznej. W epizodzie o chorych wołających ku Jezusowi z prośbą o uzdrowienie da się zauważyć, że wszyscy oni mają wiarę potrzebną do przyjęcia pożądanej łaski ${ }^{59}$. Zwracają się wspólnie do Chrystusa za pomocą zwrotu

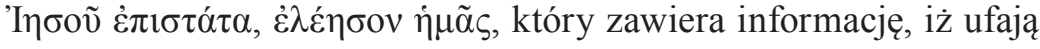
Mu jako temu, który ma moc ich uzdrowić. Wierzą, iż Jego zmiłowanie może przywrócić im zdrowie ${ }^{60}$. Jednakże tylko Samarytanin posiada wiarę, która zbawia. Wyraża się ona w postawie uniżenia aż do ziemi wobec Uzdrowiciela, którego nie tytułuje już mistrzem

7 Tamże.

58 Zob. A. Paciorek, Przypowieści Jezusa. Wprowadzenie i objaśnienie, Częstochowa 2013, s. 278n.

59 Por. F. Mickiewicz, Ewangelia wg św. Łukasza, w: NKB NT III/2, Częstochowa 2012, s. 232.

60 Tamże, s. 230n. 
notes, perhaps because of Jewish contempt and the spurned Samaritan desire to help rebuild the Temple after the return from the Babylonian captivity, they do not accept the Excluded ${ }^{56}$. The inhabitants of that village did not respect the Pilgrim and his companions. It seems that the common misery of the Jews, the worshippers connected with Mount Gerizim, as well as of the Gentiles, is the failure to accept the Lord, who came to seek and to save the lost (Cf. Lk 19:10), but had nowhere to lay his head (Cf. Lk 9:58) ${ }^{57}$.

A second reference to the Samaritans, and another stage in the evolution of Luke's attitude towards them, is found in the pericope on the Merciful Samaritan, discussed in more detail in the previous subsections. The hagiographer painted a picture of the people associated with the cult at Gerizim, quite different from the first one. Although the parabolic third passer-by did not worship God in a manner kosher for the sons of the Chosen People, he fulfilled God's instructions far better than the Jews. Jesus, in telling this parable, gave an answer to the question of the scholar of the Law about who should be called a neighbour. Jesus' parable extends the identity of neighbour to all people, and especially to brothers and sisters in need ${ }^{58}$. But this pericope also shows that the concept of the true worshipper of God is extended to all those who, like the unclean but merciful passer-by, follow the commandment of love of God and neighbour in their daily lives.

Attention is also drawn to the pericope of the ten lepers (Cf. Lk 17:11-19), which marks the peak of the evolution of the Samaritan image in the Third Gospel. In the episode about the sick crying out to Jesus for healing, it is possible to see that they all have the faith necessary to receive the desired grace ${ }^{59}$. They address Christ

${ }^{56}$ Cf. S. Fausti, The Community Reads the Gospel According to Luke [Una comunità legge il Vangelo di Luca], Częstochowa 2006, p. 376.

57 Ibid.

58 See A. Paciorek, Przypowieści Jezusa. Wprowadzenie i objaśnienie [Parables of Jesus. Introduction and Explanation], Częstochowa 2013, p. 278n.

${ }_{59}$ Cf. F. Mickiewicz, The Gospel According to Luke, in: NKB NT III/2, Częstochowa 2012, p. 232. 


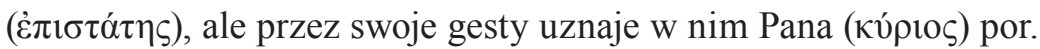
Łk 17,16-1961. Warte dostrzeżenia jest również to, że Samarytanin powracając do Chrystusa składa Mu dzięki, co zostało oddane za

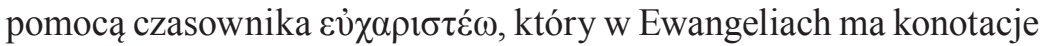
związane w modlitwą dziękczynienia, a zwłaszcza z Eucharystią ${ }^{62}$. Wdzięczny Samarytanin zdaje się nieświadomie odpowiedzieć na zachętę Chrystusa wobec Samarytanki (por. J 4,22), aby powrócić do kultu Prawdziwego Boga. Uczynił to dziękczyniąc i uznając Chrystusa Panem. Dzięki czemu staje się przykładem zarówno dla swych rodaków, jak i dla Żydów ${ }^{63}$. We wzmiankowanych perykopach trzeciej Ewangelii kanonicznej można znaleźć wspólny mianownik dotyczący kultu, co nie powinno zostać pominięte, jednakże domaga szczegółowego opracowania w osobnych artykułach.

\section{ZAKOŃCZENIE}

Podsumowując, należy podkreślić, iż wątek samarytański w trzeciej Ewangelii kanonicznej ewoluuje w miarę zbliżania się Chrystusa w swej podróży do Jerozolimy. Ewangelista Łukasz odnosi się nader życzliwie wobec cudzoziemców, których Izraelici uznawali za nieczystych. Najbardziej przełomowe w prezentacji coraz piękniejszego obrazu niekoszernych sąsiadów Izraelitów wydają się być parabola o Miłosiernym Samarytaninie oraz opis epizodu o oczyszczeniu dziesięciu trędowatych, z których jedynym wdzięcznym, oddającym prawdziwą cześć Bogu okazuje się być Samarytanin (por. Łk 17, 11-19). Można domniemywać, iż hagiograf głównie ze względu na adresatów swej Ewangelii przedstawia niezwykle korzystny w stosunku do synoptyków obraz cudzoziemców. Być może jest to przygotowanie do drugiej części Dzieła Łukaszowego, w której zostało

${ }^{61}$ Por. F. Mickiewicz, Ewangelia wg św. Łukasza, s. 230n.

${ }^{62}$ Por. J. Strong, Grecko-polski słownik Stronga, w: Prymasowska Seria Biblijna, Warszawa 2015, s. 327.

${ }_{63}$ Por. F. Mickiewicz, Ewangelia wg św. Lukasza, s. 233. 


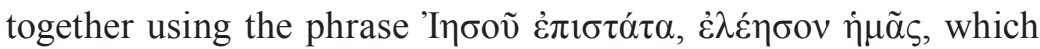
contains the information that they trust in Him as the One who has the power to heal them. They believe that His compassion can restore them to health ${ }^{60}$. However, only the Samaritan has the faith that saves. It is expressed in his attitude when he threw himself at

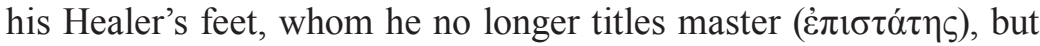

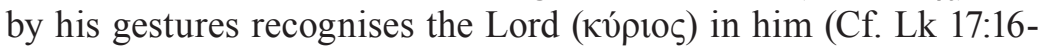
19) ${ }^{61}$. It is also worth noting that the Samaritan, returning to Christ,

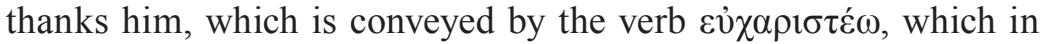
the Gospels has connotations linked to the prayer of thanksgiving and especially to the Eucharist ${ }^{62}$. The grateful Samaritan seems to have unconsciously responded to Christ's encouragement to the Samaritan woman (Cf. Jn 4:22) to return to the worship of the True God. He does so by giving thanks and acknowledging Christ as Lord. In this way, he becomes an example both to his fellow countrymen and to the Jews ${ }^{63}$. In the above-mentioned pericopes of the third Gospel, a common denominator can be found regarding worship, which should not be overlooked, but demands more detailed elaboration in separate articles.

\section{CONCLUSION}

In conclusion, it is important to note that the Samaritan theme in the third Gospel evolves as Christ approaches on his journey to Jerusalem. The evangelist Luke refers overly kindly to foreigners whom the Israelites considered unclean. The most groundbreaking in the presentation of the increasingly beautiful image of the Israelites' non-kosher neighbours seem to be the parable about the Merciful Samaritan and the description of the episode of the cleansing

\footnotetext{
60 Ibid, p. 230n.

${ }^{61}$ Cf. F. Mickiewicz, The Gospel According to Luke, p. 230n.

${ }^{62}$ Cf. J. Strong, Greek-Polish Dictionary by Strong, in: Prymasowska Seria Biblijna [The Primate's Bible Series], Warsaw 2015, p. 327.

${ }_{63}$ Cf. F. Mickiewicz, The Gospel According to Luke, p. 233.
} 
zaprezentowane, jak Boże zbawienie rozprzestrzeniło się począwszy od Jerozolimy aż do pogańskiego Rzymu.

Łukaszowe teksty poświęcone czcicielom związanym z górą Garizim uwrażliwiają i otwierają oczy odbiorców na prawdę o Bogu, który okazuje łaskę komu chce i miłosierdzie tym, wobec których jest litościwy (por. Rz 9,15) bez względu na osoby (por. Rz 2,11). Czasem niewierzący lub odwołujący się do koncepcji K. Rahnera anonimowi chrześcijanie okazują się bardziej posłuszni poleceniom Jezusa niż synowie i córki Kościoła. Podobnie jak Samarytanin, który wypełnił Boże Prawo w przeciwieństwie do kapłana i lewity. Zatem przesłanie omawianych perykop i całego Dzieła Łukaszowego winno uwrażliwiać odbiorów na szeroką perspektywę soteryczną oraz wzywać do otwartości i dialogu z każdym człowiekiem.

Chociaż zbawienie staje się udziałem ludzi przez wiarę w Chrystusa, nie należy zawężać jego horyzontu tylko do wierzących i praktykujących katolików. Podobne, ekskluzywne podejście doprowadziło zwierzchników religii mojżeszowej do chorego legalizmu i duchowej ślepoty, a w konsekwencji do odrzucenia Tego, który przyszedł do swoich (por. J 1,11). Przypowieść o miłosiernym Samarytaninie była dla faryzeuszów rewolucją nie do przyjęcia. Jednakże przyjęli ją wykluczeni, cudzołożnicy, celnicy, ubodzy, z których Jezus zbudował pierwszą wspólnotę uczniów. Przytoczone fragmenty trzeciej Ewangelii kanonicznej są zarazem kerygmatyczne i parenetyczne, ponieważ zwiastują i unaoczniają Ewangelię o Bożej miłości. Przestrzegają również przed wykluczaniem braci i sióstr ze strumieni Bożej łaski tylko z powodu ich przynależności narodowej lub wyznaniowej. Nade wszystko są jednak współcześnie niezwykle aktualnym wezwaniem do stawania się coraz bardziej miłosiernymi na wzór Ojca. 
of the ten lepers, of whom the Samaritan turns out to be the only grateful one who truly worships God (Cf. Lk 17:11-19). It can be assumed that the hagiographer, mainly because of the addressees of his Gospel, presents an extremely favourable image of foreigners in relation to the Synoptics. It might be a preparation for the second part of Luke's work, in which it is presented how God's salvation spread from Jerusalem to pagan Rome.

The texts in Luke dedicated to the worshippers associated with Mount Gerizim sensitise and open the eyes of the recipients to the truth about God who will have mercy on whom he has mercy, and will have compassion on whom he has compassion (Cf. Rom 9:15) and does not show favouritism (Cf. Rom 2:11). Sometimes non-believers or, referring to Rahner's concept, anonymous Christians prove to be more obedient to Jesus' commands than the sons and daughters of the Church. Like the Samaritan who fulfilled God's Law in contrast to the priest and the Levite. Therefore, the message of the pericopes under discussion and of the whole of the Book of Luke should sensitise the recipients to a broad soteriological perspective and call for openness and dialogue with every human being.

Although salvation comes to people through faith in Christ, one should not narrow its horizon only to the believing and practicing Catholics. A similar exclusive approach led the heads of the Mosaic religion to a sick legalism and spiritual blindness, and consequently to the rejection of the One who came to that which was his own (Cf. Jn 1:11). The parable of the merciful Samaritan was an unacceptable revolution for the Pharisees. However, it was accepted by the excluded, the adulterers, the tax collectors, the poor, from whom Jesus built the first community of disciples. These passages from the Third Gospel are both kerygmatic and parenetic, since they proclaim and reveal the Gospel of God's love. They also warn against excluding brothers and sisters from the streams of God's grace only because of their national or religious affiliation. Above all, however, they are an extremely timely call to become ever more merciful, following the example of the Father. 


\section{Streszczenie}

Niniejszy artykuł podejmuje kwestię obrazu samarytańskiego w trzeciej Ewangelii kanonicznej. Zostało w nim zarysowane tło historyczne, geneza oraz niektóre kwestie etymologiczne związane z mieszkańcami Samarii. Również został dostrzeżony i przybliżony przełomowy wpływ paraboli o Miłosiernym Samarytaninie na dotychczas jednogłośnie potępianych przez Żydów cudzoziemców. Zarówno owa parabola jak i opowiadanie o oczyszczeniu dziesięciu trędowatych, z których jedynym wdzięcznym Chrystusowi okazał się być Samarytaninem (por. Łk 17,11-18), pokazują niezwykle pozytywny obraz ,wrogów Izraela” w Ewangelii Łukaszowej. Omawiane w artykule fragmenty trzeciej Ewangelii kanonicznej są zarazem kerygmatyczne i parenetyczne, ponieważ przybliżają i przepowiadają Dobrą Nowinę o Bożej miłości oraz przestrzegają przed potępianiem drugiego człowieka jedynie z powodu jego przynależności narodowej lub religijnej. Przede wszystkim owe perykopy są wezwaniem do stawania się coraz bardziej miłosiernymi na wzór samego Boga.

Słowa kluczowe: Miłosierny Samarytanin, Samarytanie, Miłosierdzie.

\section{Bibliografia}

Ambroży z Mediolanu, Wykład Ewangelii wedtug św. Łukasza, tłum. W. Szołdrski, Warszawa 1977.

Balz, Horst, Schneider G., Exegetisches Wörterbuch zum Neuen Testament, vol. III, Stuttgart 1983, s. 633-634.

Bednarski M., Obraz Samarytan w okresie rzymskim i ich relacje ze wspólnota żydowska w świetle dziet Józefa Flawiusza, „Veritati et Caritati” 4 (2015), Częstochowa 2015, s. 37-79.

Benedykt XVI, Encyklika Deus caritas est, http://w2.vatican.va/content/benedict-xvi/pl/encyclicals/documents/ hf_ben-xvi_enc_20051225_deus-caritas-est. html [2.11.2020].

Cantalamessa R., Oblicza miłosierdzia Boga i człowieka, Częstochowa 2016, s. 133-138.

Chrostowski W., „Nic nie zostało, jak tylko samo pokolenie Judy” (2 Krl 17, 18b) - czy naprawdę? Zagłada Samarii i Królestwa Izraela oraz jej skutki, „Collectanea Theologica" 68 (1998), Warszawa 1998, s. 5-22.

Czerski J., Nowotestamentalna terminologia mitosierdzia, RBL 40 (1987) 1, Lublin 1987. 


\begin{abstract}
About the Author
The paper presents Samaritain's issue in the Gospel According to Luke. The article includes presentation of the Samaritain's history, provenience and some etymological issues of theirs name. The paper underlines Luke's view on Jewish enemies. His view is very positive and breakthrough. It stresses relevant influence of Good Samaritain's parable in Jewish references to it. The article shows evolution of Samaritain's presentation in the Third Gospel. Luke's approach to the foreigners presented in the parable of the Good Samarian and pericope about healing ten men with leprosy is an important moral imperative. Luke teaches Christians how to be open-minded and straightforward to the others.
\end{abstract}

Keywords: Good Samaritan, Samaritans Mercy

\title{
Bibliography
}

St. Ambrose, An Exposition of the Gospel According to Luke, Polish transl. W Szoldrski, Warsaw 1977.

Balz, Horst, Schneider G., Exegetisches Wörterbuch zum Neuen Testament, vol. III, Stuttgart 1983, pp. 633-634.

Bednarski M., Obraz Samarytan w okresie rzymskim i ich relacje ze wspólnota żydowską $w$ świetle dziet Józefa Flawiusza [The Image of the Samaritans in the Roman Period and Their Relations with the Jewish Community in the Light of the Works of Josephus Flavius], in: Veritati et Caritati 4 (2015), Częstochowa 2015, pp. 37-79.

http://www.vatican.va/content/benedict-xvi/en/encyclicals/documents/hf_ben-xvi_enc_20051225_deus-caritas-est.html [19.05.2021].

Cantalamessa R., The Gaze of Mercy: A Commentary on Divine and Human Mercy [Il volto della misericordia. Piccolo trattato sulla divina e sulla umana Misericordia], Polish version: Częstochowa 2016, pp. 5-22.

Czerski J., Nowotestamentalna terminologia miłosierdzia [New Testament Terminology of Mercy], RBL 40 (1987) 1, Lublin 1987.

Dogondke D., Charakter deuteronomistyczny Księgi Malachiasza. Teologiczne implikacje intertekstualnej analizy biblijnej [The Deuteronomistic Character of the Book of Malachi. Theological Implications of Intertextual Biblical Analysis], Warsaw 2013.

Dziadosz D., Lewici i kapłani w księdze Powtórzonego Prawa [Levites and Priests in the Book of Deuteronomy], in: Verbum Vitae 17 (2010), Lublin 2010. 
Dogondke D., Charakter deuteronomistyczny Księgi Malachiasza. Teologiczne implikacje intertekstualnej analizy biblijnej, Warszawa 2013.

Dziadosz D., Lewici i kapłani w księdze Powtórzonego Prawa, „Verbum Vitae” 17 (2010), Lublin 2010.

Egger R., Josephus Flavius und die Samaritaner. Novum Testamentum et Orbis Antiquus 4, Freiburg (Schweiz) - Göttingen 1986.

Fausti S., Wspólnota czyta Ewangelię wg św. Łukasza, Częstochowa 2006.

Feldman L, Josephus Attitude toward the Samaritans. A Study in Ambivalence, w: Jewish Sect, Religious Movements and Political Parties, red. M. Mor, Omaha 1992.

Flawiusz J., Dawne dzieje Izraela (Antiquitates Iudaicae), tłum. Kubiak Z., Radożycki J., red. Dąbrowski E., Poznań 1979.

Flawiusz J., Wojna żydowska (Bellum Iudaicum), tłum. Radożycki J., Poznań 1980. Florczyk Ł., Bóg Izraela w rozumieniu Nie-Izraelitów. Studium historyczno-krytyczne wybranych tradycji deuteronomistycznej historiografii (Joz-2Krl), Lublin 2018.

Franciszek, Bulla ustanawiająca nadzwyczajny Rok Jubileuszowy Miłosierdzia Misericordiae vultus, http://w2.vatican.va/content/francesco/pl/bulls/documents/ papa-francesco_bolla_20150411_misericordiae-vultus.html [01.12.2020].

Franciszek, Encykilka Fratelli tutii, http://www.vatican.va/content/francesco/pl/ encyclicals/documents/papa-francesco_20201003_enciclica-fratelli-tutti.html [01.02.2021].

Franciszek, Posynodalna adhortacja apostolska Amoris laetitia, http://w2.vatican. va/content/francesco/pl/apost_exhortations/documents/papa-francesco_esortazione-ap_20160319_amoris-laetitia.html [10.12.2020].

Gargano I., Miłosierni jak ojciec, ZFD 47 (2017), Kraków 2017, s. 24.

Górka B., Jezus wobec judaizmu i samarytanizmu w J 4,1-30.39-42, ,Scripta Biblica et Orientalia" 1 (2009), Lublin 2009.

Green J., The New International Commentary on The New Testament, Michigan 1997.

Homerski J., Kapłaństwo w Starym Testamencie, „Roczniki Teologiczne” 41 (1994), Lublin 1994, s. 15-30.

Jan Paweł II, Encyklika Dives in misericordia, http://w2.vatican.va/content/john-paul-ii/pl/encyclicals/documents/hf_jp-ii_enc_30111980_dives-in-misericordia.html [01.12.2020].

Jan Paweł ii, List Apostolski Novo millennio ineunte, http://www.vatican.va/ content/ john-paul-ii/pl/apost_letters/2001/documents/hf_jp-ii_apl_20010106_novo-millennio-ineunte.html [01.02.2021]. 
Egger R., Josephus Flavius und die Samaritaner. Novum Testamentum et Orbis Antiquus 4, Freiburg (Schweiz) - Göttingen 1986.

Fausti S., The Community Reads the Gospel According to Luke [Una comunità legge il Vangelo di Luca], Częstochowa 2006.

Feldman L, Josephus Attitude toward the Samaritans. A Study in Ambivalence, in: Jewish Sect, Religious Movements and Political Parties, ed. M. Mor, Omaha 1992.

Flavius J., Antiquitates Iudaicae, Polish transl. Kubiak Z., Radożycki J., ed. by Dąbrowski E., Poznań 1979.

Flavius J., Bellum Iudaicum, Polish transl. Radożycki J., Poznań 1980.

Florczyk Ł., Bóg Izraela w rozumieniu Nie-Izraelitów. Studium historyczno-krytyczne wybranych tradycji deuteronomistycznej historiografii (Joz-2Krl) [The God of Israel as Understood by Non-Israelites. A historical-critical study of selected traditions of Deuteronomistic historiography (Josh-2 Kings)], Lublin 2018.

Francis, http://www.vatican.va/content/francesco/en/apost_letters/documents/papa-francesco_bolla_20150411_misericordiae-vultus.html[19.05.2021].

Francis, http://www.vatican.va/content/francesco/en/encyclicals/documents/papa-francesco_20201003 enciclica-fratelli-tutti.html [19.05.2021].

Francis, http://www.vatican.va/content/francesco/en/apost_exhortations/documents/ papa-francesco_esortazione-ap_20160319_amoris-laetitia.html [19.05.2021].

Gargano I., Miłosierni jak ojciec [Merciful like Father], ZFD 47 (2017), Kraków 2017, p. 24.

Górka B., Jezus wobec judaizmu i samarytanizmu w J 4,1-30.39-42 [Jesus towards Judaism and the Samaritans in Jn 4:1-30.39-42], ,Scripta Biblica et Orientalia” 1 (2009), Lublin 2009.

Green J., The New International Commentary on The New Testament, Michigan 1997.

Homerski J., Kapłaństwo w Starym Testamencie [Priesthood in the Old Testament], in: Roczniki Teologiczne 41 (1994) 1, Lublin 1994, pp. 15-30.

John Paul II, Encyclical Dives in misericordia, http://www.vatican.va/content/ john-paul-ii/en/encyclicals/documents/hf_jp-ii_enc_30111980_dives-in-misericordia.html [19.05.2021].

John Paul II, Apostolic Letter Novo millennio ineunte, http://www.vatican.va/content/ john-paul-ii/en/apost_letters/2001/documents/hf_jp-ii_apl_20010106_novo-millennio-ineunte.html

[19.05.2021].

Koster H., $\sigma \pi \lambda \alpha ́ \gamma \chi v o v$, TDNT, vol. VII, 548n. 
Koster H., $\sigma \pi \lambda \alpha \dot{\gamma} \chi \chi v o v$, TDNT, vol. VII, 548n.

Mędala S., Ewangelia wg św. Jana. Wstęp, przekład z oryginatu, komentarz, NKB NT IV/1, Częstochowa 2010, s. 464n.

Mickiewicz F., Ewangelia wg św. Łukasza. Wstęp, przekład z oryginału, komentarz, NKB NT III/1, Częstochowa 2011.

Mickiewicz F., Ewangelia wg św. Łukasza. Wstęp, przekład z oryginału, komentarz, NKB NT III/2, Częstochowa 2012.

Paciorek A., Przypowieści Jezusa. Wprowadzenie i objaśnienie, Częstochowa 2013. Pikor W., Przypowieści Jezusa. Narracyjny klucz lektury, Kielce 2011.

Pronzato A., Śladami Samarytanina, Kraków 2016.

Rienecker F., Maier G., Leksykon biblijny, w: Prymasowska Seria Biblijna, Warszawa 2001.

Rosik M., Ze wzgórz Samarii, Wrocław 2005.

Stein R., The interpretation of the Parable of the Good Samaritan, Grand Rapids Michingan 1978.

Strong J., Grecko- polski słownik Stronga, w: Prymasowska Seria Biblijna, Warszawa 2015.

Sung L., Josephus constructs the Samari(t)ans: A strategic Construction of Judean/ Jewish Identity through the rhetoric of Inclusion and Exclusion, w: Journal of Theological Studies 64 (2013), Oxford 2013, s. 429-431.

Szmajdziński M., Ideał kapłana w księdze Ozeasza, „Verbum Vitae” 17 (2010), Lublin 2010, s. 69-105.

Uchnast Z., Empatia jako postawa egzystencjalna, „Roczniki Filozoficzne” t. 44, z. 4, 1996: 37-52.

Wailes S., Medieval allegories of Jesus' parables, Berkeley 1987.

Warzecha J., Historia Dawnego Izraela, Warszawa 2005.

Wypych S., Samarytanie w ujęciu historycznym, geograficznym i religijnym, w: RBL 3 (2005), Lublin 2005, s. 171n. 
Mędala S., Ewangelia wg św. Jana [The Gospel According to John], in: NKB NT IV/1, Częstochowa 2010, p. 464n.

Mickiewicz F., Ewangelia wg św. Łukasza. Wstęp, przekład z oryginału, komentarz [The Gospel According to Luke], NKB NT III/1, Częstochowa 2011.

Mickiewicz F., Ewangelia wg św. Łukasza. Wstęp, przekład z oryginału, komentarz [The Gospel According to Luke], NKB NT III/2, Częstochowa 2012.

Paciorek A., Przypowieści Jezusa. Wprowadzenie i objaśnienie [Parables of Jesus. Introduction and Explanation], Częstochowa 2013.

Pikor W., Przypowieści Jezusa. Narracyjny klucz lektury [Parables of Jesus. Narrative Key to Reading], Kielce 2011.

Pronzato A., In the Footsteps of the Samaritan [Sulle tracce del samaritano. Pellegrinaggio al santuario dell'uomo], Polish version: Kraków 2016.

Rienecker F., Maier G., Dictionary of the Bible [original: Lexikon zur Bibel], in: Prymasowska Seria Biblijna [Primate Bible Serie], Warsaw 2001.

Rosik M., Ze wzgórz Samarii [From the Hills of Samaria], Wrocław 2005.

Stein R., The interpretation of the Parable of the Good Samaritan, Grand Rapids Michingan 1978.

Strong J., Greek-Polish Dictionary by Strong, in: Prymasowska Seria Biblijna [The Primate's Bible Series], Warsaw 2015.

Sung L., Josephus constructs the Samari(t)ans: A strategic Construction of Judean/ Jewish Identity through the rhetoric of Inclusion and Exclusion, in: Journal of Theological Studies 64 (2013), Oxford 2013, pp. 429-431.

Szmajdziński M., Ideał kapłana w księdze Ozeasza [The Ideal of a Priest in the Book of Hosea], in: Verbum Vitae 17 (2010), Lublin 2010, pp. 69-105.

Uchnast Z., Empatia jako postawa egzystencjalna [Empathy as an Existential Attitude], „Roczniki Filozoficzne” vol. 44, issue 4, 1996: 37-52.

Wailes S., Medieval allegories of Jesus' parables, Berkeley 1987.

Warzecha J., Historia Dawnego Izraela [History of Ancient Israel], Warsaw 2005.

Wypych S., Samarytanie w ujęciu historycznym, geograficznym i religijnym [Samaritans in Historical, Geographical and Religious Perspective], in: RBL 3 (2005), Lublin 2005, p. 171n. 